\title{
Life cycle assessment of onshore and offshore wind energy - from theory to application
}

Bonou, Alexandra; Laurent, Alexis; Olsen, Stig Irving

Published in:

Applied Energy

Link to article, DOI:

10.1016/j.apenergy.2016.07.058

Publication date:

2016

Document Version

Peer reviewed version

Link back to DTU Orbit

Citation (APA):

Bonou, A., Laurent, A., \& Olsen, S. I. (2016). Life cycle assessment of onshore and offshore wind energy - from theory to application. Applied Energy, 180, 327-337. https://doi.org/10.1016/j.apenergy.2016.07.058

\section{General rights}

Copyright and moral rights for the publications made accessible in the public portal are retained by the authors and/or other copyright owners and it is a condition of accessing publications that users recognise and abide by the legal requirements associated with these rights.

- Users may download and print one copy of any publication from the public portal for the purpose of private study or research.

- You may not further distribute the material or use it for any profit-making activity or commercial gain

- You may freely distribute the URL identifying the publication in the public portal

If you believe that this document breaches copyright please contact us providing details, and we will remove access to the work immediately and investigate your claim. 


\title{
Life cycle assessment of onshore and offshore wind energy: from theory to application
}

\author{
Alexandra Bonou ${ }^{1 *}$, Alexis Laurent ${ }^{1}$, Stig I. Olsen ${ }^{1}$ \\ ${ }^{1}$ Division for Quantitative Sustainability Assessment, Department of Management Engineering, Technical University \\ of Denmark, 2800 Kgs. Lyngby, Denmark
}

* To whom correspondence should be addressed; e-mail: abon@dtu.dk, Tel.: (+45) 53234656

\begin{abstract}
This study aims to assess the environmental impacts related to the provision of $1 \mathrm{kWh}$ to the grid from wind power in Europe and to suggest how life cycle assessment can inform technology development and system planning. Four representative power plants onshore (with 2.3 and $3.2 \mathrm{MW}$ turbines) and offshore (4.0 and 6.0 MW turbines) with 2015 state-of-the-art technology data provided by Siemens Wind Power were assessed. The energy payback time was found to be less than 1 year for all technologies. The emissions of greenhouse gases amounted to less than $7 \mathrm{~g} \mathrm{CO}$-eq/kWh for onshore and $11 \mathrm{~g} \mathrm{CO2-eq/kWh}$ for offshore. Climate change impacts were found to be a good indicator for overall hotspot identification however attention should also be drawn to human toxicity and impacts from respiratory inorganics. The overall higher impact of offshore plants, compared to onshore ones, is mainly due to larger high-impact material requirements for capital infrastructure. In both markets the bigger turbines with more advanced direct drive generator technology is shown to perform better than the smaller geared ones. Capital infrastructure is the most impactful life cycle stage across impacts. It accounts for more than $79 \%$ and $70 \%$ of climate change impacts onshore and offshore respectively. The end-of-life treatment could lead to significant savings due to recycling, ca. 20-30\% for climate change. In the manufacturing stage the impacts due to operations at the case company do not exceed $1 \%$ of the total life cycle impacts. This finding highlights the shared responsibility across multiple stakeholders and calls for collaborative efforts for comprehensive environmental management across organizations in the value chain. Real life examples are given in order to showcase how LCA results can inform decisions, e.g. for concept and product development and supply chain management. On a systems level the results can be used by energy planners when comparing with alternative energy sources.
\end{abstract}

\section{Keywords}

wind turbine, wind power plant, sustainability, wind energy, energy payback time

\section{Introduction}

Energy planners need to keep the pace in satisfying an electricity demand which has doubled since 1990 and is expected to grow by $80 \%$ by 2040 [1]. In parallel the need for a low carbon economy due to environmental and energy security issues calls for higher deployment of renewable energy sources (RES) to the electrical grids around the globe [2]. In a European context wind power is the fastest growing renewable energy source. The European Wind Energy Association (EWEA) expects that by 2030 the 
Bonou A, Laurent A, Olsen SI (2016) Life cycle assessment of onshore and offshore wind energy-from theory to application. Appl Energy 180:327-337. doi: 10.1016/j.apenergy.2016.07.058

capacity will have increased to $320 \mathrm{GW}$ compared to $129 \mathrm{GW}$ in 2014. By that time wind energy is expected to meet more than $24 \%$ of EU's projected electricity demand $[3,4]$.

There is abundance of literature dealing with technical aspects of wind energy. These include technological innovations such as the direct drive generators [5]; measurement of wind data e.g. through the use of LIDARs and satellites [6,7]; grid integration technologies covering also issues of transmission and storage [8,9]; wind power prediction methods driven by technological and market aspects [10-12]. Contrary, a review prepared for the Smart Energy for Europe Platform concludes that the conceptual aspects of wind energy system planning are less covered. It also suggests to adopt a systems perspective for transitioning to low carbon economy [13]. More recent literature adds that strategic environmental assessment (SEA) is of key importance for promoting sustainable wind energy planning [14].

This dual need for environmental assessment and for a more systemic management and planning can be addressed by Life Cycle Assessment (LCA) $[15,16]$. This is a state of the art methodology for assessing multiple environmental impacts of a system over time and space throughout its lifecycle from cradle to grave, i.e. from extraction of the materials through production and use or operation of the system till its end-of-life (EoL) [17]. The Intergovernmental Panel on Climate Change (IPCC) suggests to policy makers that LCA is' a particularly useful methodology for determining total system impacts of a given technology' [18]. LCA can serve on a systems level for meso-large scale policy evaluations. Foidard et al. use it to assess implications of renewables' integration into the grid. Berril et al. assess 44 scenarios of electricity supply in the EU in 2050. Lund et.al further investigate the impacts due to changes in long term marginal technologies. Aside energy production, consumption aspects are also assessed, e.g. Rodriguez et al. coevaluate energy demand and supply patterns. Laurent and Espinoza highlight the methodology's potential for foresight studies [19-23]. LCA is also used on a technology level, for evaluating power plants and their components. Within RES, LCA studies are found for the frequently controversial sector of bioenergy production (1st-3rd generation biofuels), [24-27] and for photovoltaic applications [28].

In the wind energy sector LCA studies cover a wide spectrum of research areas. Some investigate countryspecific environmental improvement potentials, e.g. Xue et al. do it for China [29]. Others explore differences due to geographical differentiation, e.g. Lenzen et al. compare the energy embodied in wind turbines in Brazil and Germany [30]. Many assess different technologies and application settings ranging from rooftop microgeneration applications to multimegawatt wind turbines [31-33]. Yet, literature gaps and limitations can be identified: (i) offshore is less covered compared to onshore. As illustrated in the comprehensive critical meta-analysis of Nugent and Sovacool [34], only 2 out of 22 qualified studies assessed offshore wind power systems (ii) the assessments do not consistently account for all the life cycle. In their review of 44 studies of wind power, Arvesen and Hertwich find that the "use" and particularly "end-of-life" (EoL) stages are partially covered or omitted [35] (iii) environmental impacts are not fully covered. The same review notes that most LCA studies consider only greenhouse gas emissions and energy demand. This narrow focus, may lead to oversimplifications regarding the "environmental" performance of the assessed systems (iv) there is shortage of examples on how to integrate the LCA learnings into daily practices. Discussion on the value added by LCA when integrated in decision making is limited and therefore companies and policy makers are still striving to proactively use LCA in the front end of their planning. 


\section{Bonou A, Laurent A, Olsen SI (2016) Life cycle assessment of onshore and offshore wind energy-from}

theory to application. Appl Energy 180:327-337. doi: 10.1016/j.apenergy.2016.07.058

To address the identified gaps, we conducted iterative LCA studies in the applied setting of Siemens Wind Power. The company is amongst the three largest wind turbine manufacturers in the world in 2014, holding more than $86 \%$ of the European offshore market $[36,37]$. Furthermore, it influences several activities across the wind turbines' life cycle i.e. design, manufacturing, installation, service etc. Our two research objectives were:

(i) to provide an understanding of the environmental impacts of state of the art wind power technologies

(ii) to showcase how LCA results can inform technology and system planning

The structure of the paper is as follows: Section 2 presents four wind power plants, their boundaries and the corresponding data used for assessing their life cycle. Section 3 presents the assessment results and identifies environmental hotspots. Section 4 relates the results to decisions taken for wind power technology development. Real life examples from the case company are presented and the potential for further LCA integration in technology and system planning is discussed. Section 5 concludes the study and provides recommendations for further research.

\section{Methods and materials}

\subsection{Wind power plants: service and system description}

The LCAs were conducted according to the International Reference Life Cycle Data System (ILCD) Handbook for LCA [17]. As a first step the goal (i.e. the purpose) and scope (i.e. what to analyse and how) were identified. The goals of the LCAs and the intended applications coincide with the research objectives in Section 1. In terms of scope, the functional unit (FU), which reflects the primary function of the system and is the basis of the LCA [38], was defined as "the average supply of $1 \mathrm{kWh}$ electricity delivered to the grid". To ensure technological and market representativeness, SWP planners and experts provided inputs to define the technical specifications and the size of representative European wind power plants based on 2013 data and near future sales. Both onshore and offshore technologies were assessed separately since (i) they have different economic, technological and operational particularities, e.g. in relation to the grid connection [39], and (ii) offshore is emerging as an important player in future electricity grids. In fact Esteban and Leary estimate that by 2050 around $5.5 \%$ of the world's electricity could come from offshore wind [40]. Since it is less covered in literature, thus making its separated assessment a valuable information for researchers and stakeholders at large.

Four plants were therefore defined, covering onshore and offshore systems, each being further differentiated into the two major power generating technologies, viz. direct drive and geared-based. Table 1 provides a detailed overview of these four power plants. 
Bonou A, Laurent A, Olsen SI (2016) Life cycle assessment of onshore and offshore wind energy-from theory to application. Appl Energy 180:327-337. doi: 10.1016/j.apenergy.2016.07.058

Table 1. Technical specifications of the assessed wind power plants. In the plant names the letter corresponds to generator technologies direct drive (D) and geared (G) and the number to the turbines' capacity (MW).

\begin{tabular}{|c|c|c|c|c|c|c|c|c|c|}
\hline Market & $\begin{array}{c}\text { Plant } \\
\text { name }\end{array}$ & $\begin{array}{c}\text { Turbine } \\
\text { (MW-rotor } \\
\text { diameter) }\end{array}$ & $\begin{array}{c}\text { Hub } \\
\text { height } \\
(\mathrm{m})\end{array}$ & $\begin{array}{c}\text { Wind } \\
\text { speed } \\
(\mathrm{m} / \mathrm{s})\end{array}$ & $\begin{array}{c}\text { Loss } \\
(\%)\end{array}$ & $\begin{array}{c}\text { Energy to grid } \\
\text { /turbine/year } \\
(\mathrm{MWh})\end{array}$ & $\begin{array}{c}\text { Lifetime } \\
(\mathrm{y})\end{array}$ & $\begin{array}{c}\text { Turbines } \\
/ \text { park } \\
(\mathrm{nr})\end{array}$ & $\begin{array}{c}\text { Cable } \\
\text { distance } \\
\text { /turbine }(\mathrm{km})\end{array}$ \\
\hline \multirow{2}{*}{ onshore } & $\mathrm{G} 2$ & $2.3-108$ & 99.5 & 8.5 & 10 & 11169 & 20 & 20 & 13 \\
\cline { 2 - 10 } & $\mathrm{D} 3$ & $3.2-113$ & 92.5 & 8.5 & 10 & 14403 & 20 & 20 & 13 \\
\hline \multirow{2}{*}{ offshore } & $\mathrm{G} 4$ & $4.0-130$ & 68.25 & 9.5 & 15 & 20528 & 20 & 80 & $30 / 22^{* *}$ \\
\cline { 2 - 9 } & $\mathrm{D} 6$ & $6.0-154$ & 87.72 & 10 & 15 & 31045 & 25 & 80 & $50 / 22^{* *}$ \\
\hline
\end{tabular}

wake, electrical and availability losses,

${ }^{* *}$ sea/land

The systems were set to include all wind power plant components from the power station (i.e. turbine) up to the distribution wiring. Back-up and energy storage systems were excluded. The system boundaries (Figure 1) included the life cycle of the plants from extraction of raw materials to the EoL. Since this is a descriptive study aiming to document the analysed system, the modelling principle for the life cycle inventory followed an attributional LCA approach [17]. We addressed multi-functionality of processes by use of system expansion. For example, in the waste treatment stage, recycling lead to materials recovery, thus avoiding respective production from virgin sources (Figure 1 and Table 3). Potential structural consequences on other systems i.e. long term implications to the grid due to increased installed capacity were out of scope. Out of scope was also the detailed exploration of future treatment technologies of blade recycling $[41,42]$.

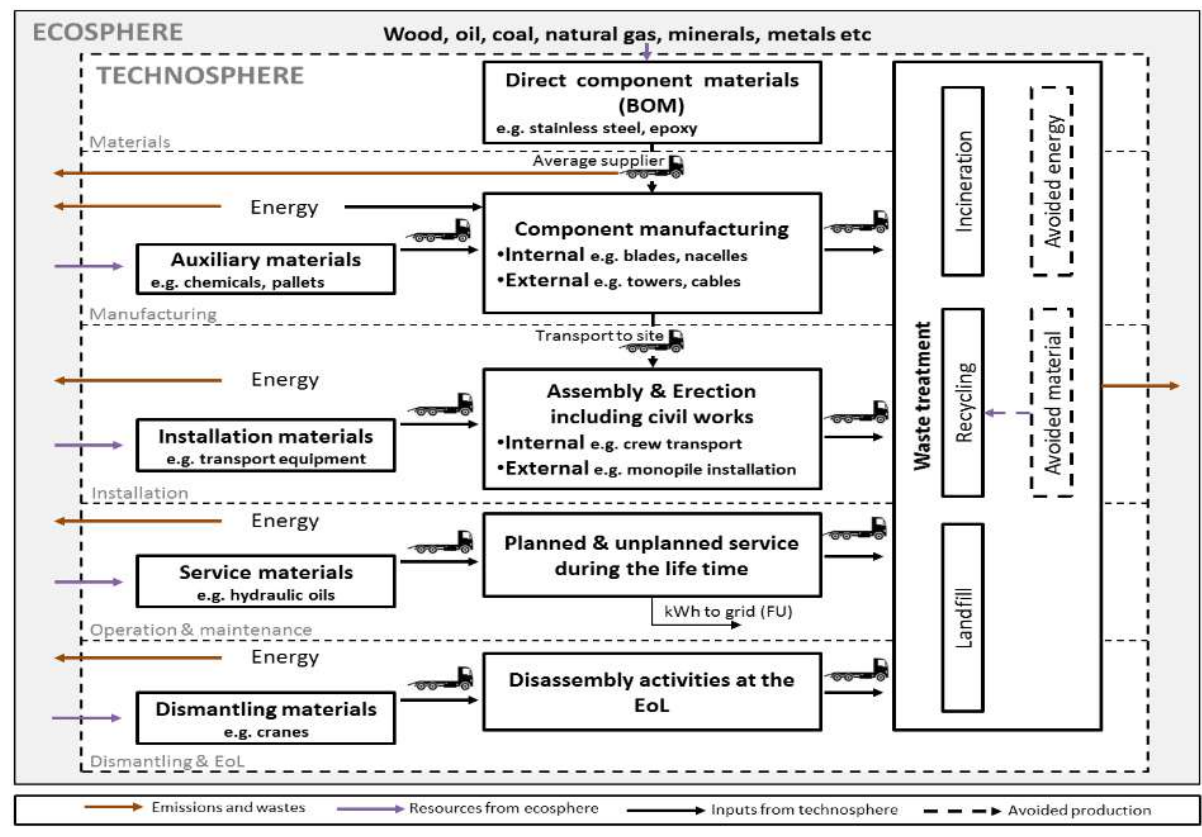

Figure 1. System boundaries covering all life cycle stages of all wind power plants 


\subsection{Inventory data collection and modelling}

Data were collected for each stage of the system's life cycle (Figure 1). Detailed accounts of all items included in the inventory are given in Table S1 of Supporting Information (SI). Primary data were collected internally in SWP from material experts, engineers, etc. and externally from suppliers and operators. The difference between the onshore and offshore plants is mostly seen in relation to installation, i.e. the onshore plants require the construction of gravel roads while offshore installations require operations at sea. The two also differ in terms of infrastructure materials such as cabling and foundations, e.g. steel reinforced concrete is used for onshore foundations while steel monopiles are used offshore. The aggregated inventories for infrastructure materials are given in Table 2.

Table 2. Aggregated inventory for capital infrastructure (turbines, foundations, substations, cabling)

\begin{tabular}{|l|l|l|l|}
\hline \multicolumn{2}{|c|}{ Onshore plants (average G2\&D3) } & \multicolumn{2}{c|}{ Offshore plants (average G4\&D6) } \\
\hline Infrastructure (t) & $3.57 \mathrm{E}+04$ & Infrastructure (t) & $1.42 \mathrm{E}+05$ \\
\hline \hline Infrastructure materials & $\mathbf{w t} \%$ & Infrastructure materials & wt\% \\
\hline Concrete & $72.8 \%$ & Steel & $73 \%$ \\
\hline Steel & $20.5 \%$ & Iron & $6.4 \%$ \\
\hline Iron & $1.8 \%$ & Concrete & $4.7 \%$ \\
\hline Epoxy & $1.2 \%$ & Plastics & $3.6 \%$ \\
\hline Glass fibre & $1 \%$ & Epoxy & $2.4 \%$ \\
\hline Plastics & $0.8 \%$ & Glass fibre & $2.3 \%$ \\
\hline Aluminium & $0.7 \%$ & Aluminium & $2 \%$ \\
\hline Copper & $0.7 \%$ & Copper & $1.4 \%$ \\
\hline Wood & $0.2 \%$ & Lead & $1 \%$ \\
\hline
\end{tabular}

The EoL of the power plants consists of management of construction and demolition (C\&D) wastes and is expected to take place in 2040. Modelling assumptions for the EoL of infrastructure equipment, summarized in Table 3, were based on expert knowledge within SWP and literature. To model the avoided production of electricity from incineration, the composition of the future grid was adjusted to the 'symphony' scenario from the World Energy Council (i.e. coal 11\%, gas $25 \%$, Nuclear $22 \%$, hydro $16 \%$, biomass $6 \%$, wind $13 \%$, solar $7 \%$ ) [43].

Table 3. Modelling assumptions for the EoL treatment of the main materials in wind power plant systems

\begin{tabular}{|l|l|l|l|}
\hline Waste type & \% collected & Treatment method & Avoided product \\
\hline Metals & $\begin{array}{l}\text { 50\% from all } \\
\text { foundations and } \\
\text { offshore cables/ } \\
90 \% \text { from all other } \\
\text { components }\end{array}$ & $\begin{array}{l}\text { Recycling (energy } \\
\text { requirements based on } \\
{[44]}\end{array}$ & $\begin{array}{l}\text { Average material in the market; substitution rate } \\
90 \mathrm{wt} \%\end{array}$ \\
\hline Plastics & $100 \%$ & $\begin{array}{l}\text { Incineration (based on } \\
\text { ecoinvent v3.1) }\end{array}$ & $\begin{array}{l}\text { Electricity and heat based on the lower heating } \\
\text { values from ecoinvent v3.1 }\end{array}$ \\
\hline & & $\begin{array}{l}\text { Shredding (28kW/t) and } \\
\text { incineration in cement } \\
\text { production }\end{array}$ & $\begin{array}{l}\text { Epoxy substitutes heavy fuel. Substitution rate } \\
\text { based on the calorific values of epoxy 32 MJ/kg } \\
{[45] \text { and heavy fuel oil 43MJ } / \mathrm{kg}} \\
\text { Glass fibre substitutes sand (40\%) and clay (60\%) }\end{array}$ \\
\hline Blades & $100 \%$ & $\begin{array}{l}\text { Recycling (crushing based } \\
\text { on ecoinvent v3.1) }\end{array}$ & Crushed gravel; substitution rate $90 \mathrm{wt} \%$ \\
\hline Concrete & $50 \%$ & Recycling & Crushed gravel; substitution rate $90 \mathrm{wt} \%$ \\
\hline Gravel & $75 \%$ & \multicolumn{2}{|l}{} \\
\hline
\end{tabular}




\section{Bonou A, Laurent A, Olsen SI (2016) Life cycle assessment of onshore and offshore wind energy-from}

theory to application. Appl Energy 180:327-337. doi: 10.1016/j.apenergy.2016.07.058

For modelling the background processes, e.g. extraction of the materials, waste treatment etc., the study relied on generic data from ecoinvent v3.1 [46]. All EoL operations, e.g. the use of fuel for dismantling and the avoided production of materials, were modelled using background data based on ecoinvent v.3.1 without technological adjustment.

The EoL is the life cycle stage least covered in wind power LCAs and is associated to several uncertainties [47]. Temporal ones are due to the long life time of the plants and the difficulty in predicting future markets and corresponding treatment technologies, e.g. there are currently no economically viable recycling technologies for glass fibre composite materials [48]. Uncertainty is enhanced by the lack of inventory data for existing technologies such as recycling of metals as well as the geographical differentiation of recycling rates (i.e. collection and recovery) [49,50]. Policy wise, in EU the current political target set by the Waste Framework Directive aims at 70\% recycling of non-hazardous C\&D waste by 2020 [51].

\subsection{Impact assessment indicators}

Of primary interest for SWP was the system's contribution to climate change. This was assessed via the IPCC findings [52]. Another indicator commonly characterizing electrical power generation and renewable energy technologies is energy payback time (EPBT) [53]. This is defined as the amount of time that the system needs to run in order to produce the amount of energy equivalent to the primary energy consumed throughout its life time. EPBT was assessed via the impact assessment methodology Cumulative Energy Demand (CED) v1.09, based on the method published by ecoinvent version 2.0 [54]. In addition to climate change, all ILCD recommended impact categories [55] at a midpoint level, were assessed (see Figure 2). The impact assessment was also done at endpoint level using ReCiPe methodology, where the emissions are related to their damages to the three areas of protection: ecosystems quality, human health and natural resources [56]. Endpoint assessments are less accurate since causal links between emissions and impacts are weaker [57]. However, the approach is more complete since the entire impact pathway is accounted for. The systems were modelled in SimaPro software v.8.1 
Figure 2. Mid- and end-point environmental impact categories assessed [17]

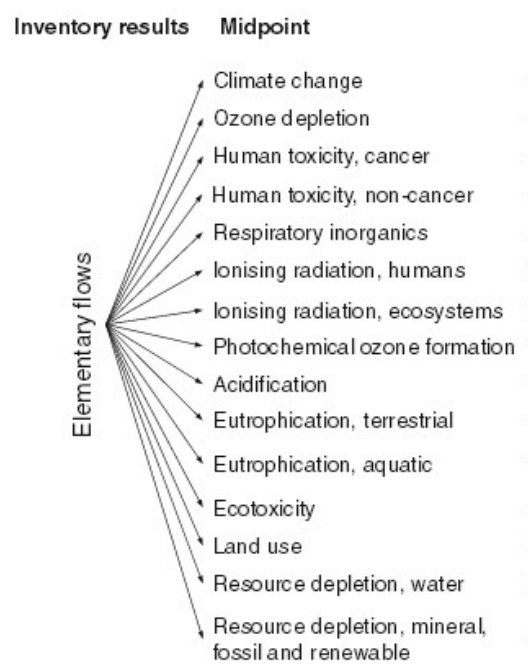

Endpoint Area of protection

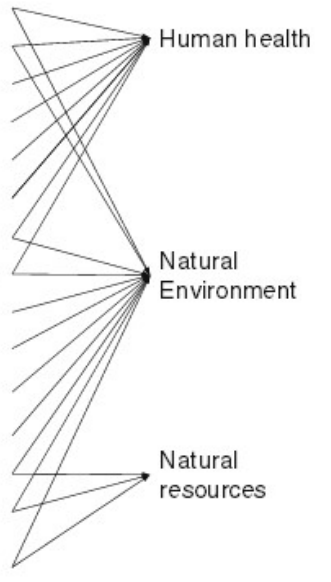

Based on the results a deterministic sensitivity analysis was done considering worst and best case scenarios for main uncertainties (i.e. metal collection rates), key assumptions (i.e. recycling substitution potentials) and for the system's technical specifications given in Table 1. An additional probabilistic Monte Carlo simulation was done to calculate the uncertainty range of the reference scenarios based on the inherent uncertainties of the life cycle inventory used in ecoinvent v3.1. Uncertainties in impact assessment were not taken into account since there are no corresponding data. The combined effect of software and database choices is also expected to influence the final results but it was out of the scope to analyse it further.

\section{Environmental performances of the four wind power plant systems}

\subsection{Carbon footprint and energy payback time}

The climate change impacts during the life cycle of onshore and offshore plants are less than 7 and $11 \mathrm{~g}$ $\mathrm{CO}_{2}$-eq/kWh , respectively. The energy payback time is less than 1 year (Table 4). The results imply the potential GHG savings from deploying high shares of wind energy to the grid. For comparison, in Denmark, climate change impacts from fossil sources amount to $990 \mathrm{~g} \mathrm{CO}_{2}$-eq/kWh for coal and $530 \mathrm{~g} \mathrm{CO}_{2}$-eq/kWh for natural gas [58] which are thus approximately 100 times higher than the results.

Table 4. LCA results for climate change and energy payback time.

\begin{tabular}{|c|c|c|c|c|}
\hline Market & $\begin{array}{c}\text { Plant } \\
\text { name }\end{array}$ & $\begin{array}{c}\text { Turbine } \\
\text { (MW-rotor } \\
\text { diameter) }\end{array}$ & $\begin{array}{c}\text { Climate Change } \\
\mathrm{g} \mathrm{CO}_{2} \text {-eq/kWh }\end{array}$ & $\begin{array}{c}\text { EPBT } \\
\text { (months) }\end{array}$ \\
\hline onshore & $\mathrm{G} 2$ & $2.3-108$ & 6.0 & 6.2 \\
\cline { 2 - 5 } & $\mathrm{D} 3$ & $3.2-113$ & 5.0 & 5.2 \\
\hline \multirow{2}{*}{ offshore } & $\mathrm{G} 4$ & $4.0-130$ & 10.9 & 11.1 \\
\cline { 2 - 5 } & $\mathrm{D} 6$ & $6.0-154$ & 7.8 & 10 \\
\hline
\end{tabular}




\section{Bonou A, Laurent A, Olsen SI (2016) Life cycle assessment of onshore and offshore wind energy-from theory to application. Appl Energy 180:327-337. doi: 10.1016/j.apenergy.2016.07.058}

The system's sensitivity to major assumptions was done through a scenario analysis considering worst and best cases for most influential and uncertain factors. These were (i) the technical specifications given in Table 1, i.e. the wind speed, efficiency and life time, which are independent from the $\mathrm{LCl}$ modelling but they are determining the $\mathrm{kWh}$ delivered to the grid therefore directly influencing the results per FU; (ii) major EoL assumptions in Table 3, i.e. the C\&D collection rate for the foundation materials and the rate with which secondary steel substitutes primary production. Assumptions that do not have significant influence on the results have not been tested for sensitivity. This is the case of future grid composition, which affects the impacts from incineration at the EoL.

The sensitivity analysis results for the D6 plant, which are representative for all plants are given in Figure 3. This tornado diagram allows to see the relative importance of the factors and the system's sensitivity to each of them ceteris paribus. The system is mostly sensitive to its technical specifications which is aligned with what other literature suggests [59].

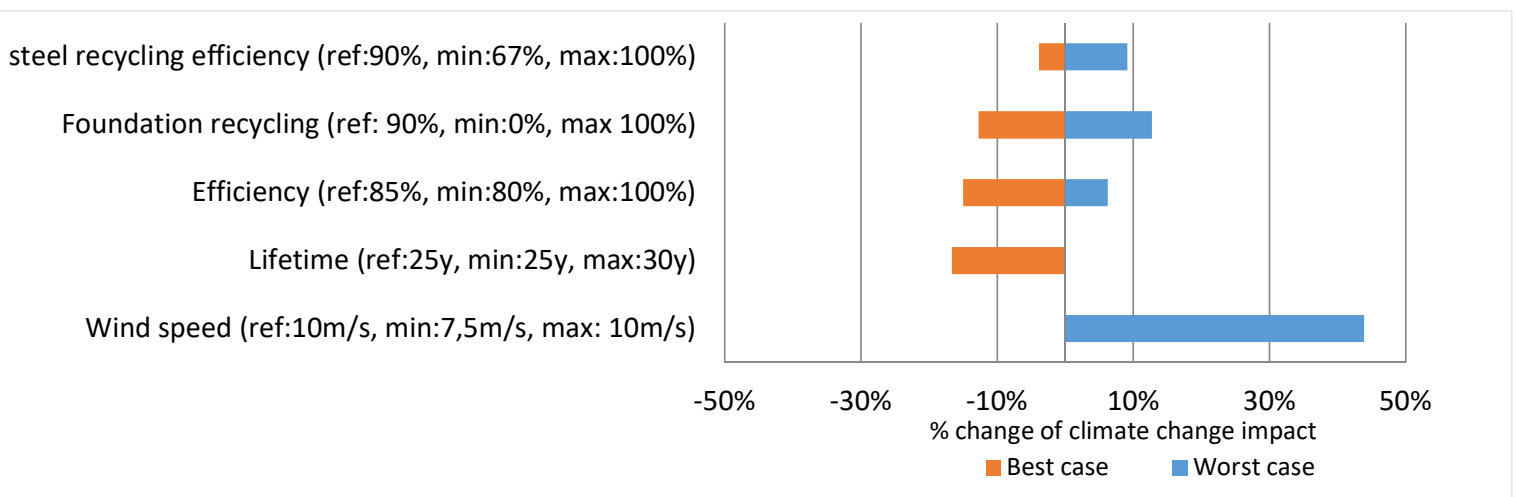

Figure 3. Change (\%) of climate change impact of the D6 plant due to change in assumptions ceteris paribus

\subsubsection{Comparisons within and across markets}

In both markets drivers for better performance are (i) the advanced technology i.e. direct drive generators and optimized blade design, and (ii) the size i.e. the newer turbines are bigger, with approximately $22 \%$ less material weight per $\mathrm{kWh}$ delivered to the grid. This result is aligned with the economies of scale effect discussed by Tremeac and Meunier analysing a $4.5 \mathrm{MW}$ and a 250W onshore turbine [60], as well as from Lenzen and Munksgaard after conducting a comprehensive review of 72 wind energy studies [61]. In this study it is not possible to distinguish between those two causes for attributing the better performance. Caduf et al. who also reach the conclusion that bigger is better, note that experience and innovation contribute to a better environmental performance [62].

Across markets, the greenhouse gas emissions per kWh delivered to the grid for the life cycle of the offshore plants are approximately $70 \%$ higher than onshore. This finding, is due to (i) the higher requirements in capital infrastructure which is both heavier (Table 2) and more impact dense (see also Figure 8) compared to onshore, and (ii) resource intense operations offshore, particularly for installation and decommissioning stages (see also Table 5 and Table S3 of SI). These two factors counterbalance the benefits of higher energy output. 


\section{Bonou A, Laurent A, Olsen SI (2016) Life cycle assessment of onshore and offshore wind energy-from}

theory to application. Appl Energy 180:327-337. doi: 10.1016/j.apenergy.2016.07.058

Relating the results to other literature

The results are consistent with and in the lower range of the values reported by IPCC for renewable energy. Wiser et al. made a comprehensive review of 49 wind energy LCA studies ( 44 for onshore and 12 offshore) published since 1980 and they report lifecycle GHG emissions between $8-20 \mathrm{~g} \mathrm{CO}_{2}$-eq/kWh with a median at $12.5 \mathrm{~g} \mathrm{CO}_{2}$-eq/ $\mathrm{kWh}$. They, in line with the present study and with other literature find offshore more impactful than onshore per kWh delivered [59,63]. Comparing to studies assessing systems similar to the ones in Table 1: (i) for onshore, Martinez et al. find $6.6 \mathrm{~g} \mathrm{CO}_{2}$-eq/kWh (2MW Gamesa turbine with $80 \mathrm{~m}$ rotor blade and $70 \mathrm{~m}$ hub height for Spanish conditions) [64]. Garret and Ronde find 7-10 g CO $2^{-}$ eq/kWh for various $2 \mathrm{MW}$ Vestas onshore turbines [65]. Regarding the EPBT, Haapala et al. report values between 5.4 and 6.2 months for a $2 \mathrm{MW}$ turbine [32], (ii) for offshore the results are consistent with Dolan [66] who reviews 2 empirical and 3 theoretical offshore studies and reports average values between 9.4 and $14 \mathrm{~g} \mathrm{CO}_{2}$-eq/kWh. The critical meta review by Nugent and Sovacool [34], includes only one study for UK with a contribution to $13.4 \mathrm{~g} \mathrm{CO}_{2}$-eq/kWh [67].

\subsection{Environmental hotspots and contribution analyses}

LCA results were used to identify hotspots in two dimensions: across the life cycle of the product and within each life cycle stage to the maximum resolution level according to the available data. As Figure 4 shows for climate change, most of the impacts are due to extraction and production of materials (hereafter called 'materials'). This stage contributes more than $79 \%$ and $70 \%$ to the climate change impact onshore and offshore respectively. These results are in line with the $78 \%$ material contribution to climate change impacts reported by Haapala and Prempreeda and the $84 \%$ contribution reported by Guezuraga et al.; both referring to $2 \mathrm{MW}$ onshore wind power $[32,68]$. Likewise the results are consistent with IPCC conclusion that capital infrastructure is the most determining factor for the systems' environmental performance which is the case for most renewable energy sources $[59,69]$.

Given the domination of materials in the overall impacts, their treatment and recycling at the EoL of the plants is consequently important and leads to environmental savings due to the avoided production of materials (mainly metals) through system expansion (Figure 1) (see Tables S2 and S3 of SI). These savings need to be interpreted in relation to the assumptions made on the future treatment of the turbine components (Table 2). For example, assuming economic allocation for the substitution of steel based on secondary steel price $(67 \%)$ instead of the reference assumption (90\%) there is approximately $11 \%$ change in the LCA results for climate change (see Figure 3). 


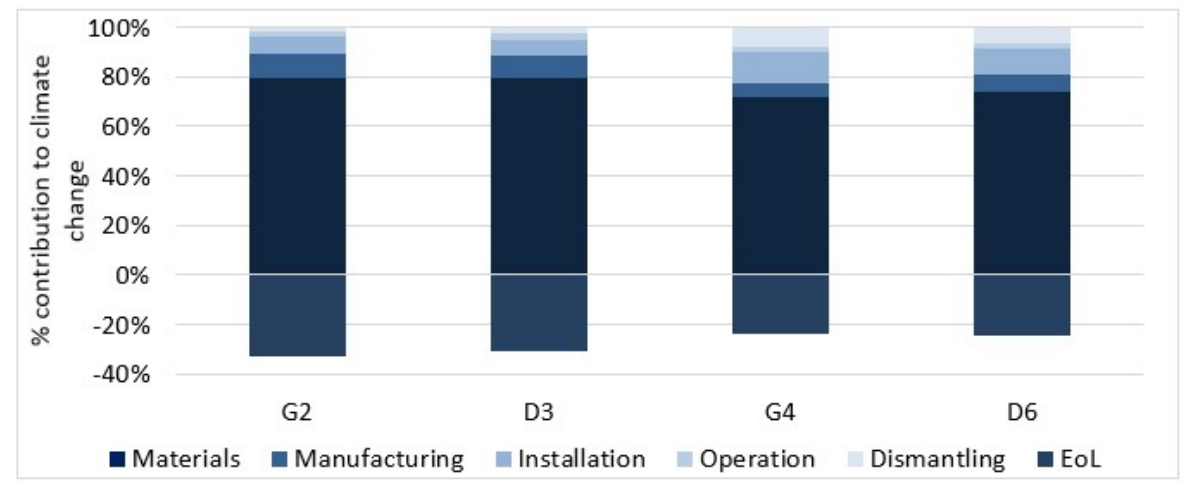

Figure 4. Percent contribution of life cycle stages to the total impact for the four assessed wind energy plants: onshore (G2, D3) and offshore (G4, D6)

\subsubsection{Impacts from infrastructure materials}

Figures 5 and 6 focus on the LCA results for 'materials' for all ILCD recommended impact categories [55]. Cut off is set to $1 \%$ contribution to climate change. With the exception of the impacts related to land use, where installation stage is most relevant due to the road construction, impacts from 'materials' prevail across impact categories (see also Tables S2 and S3 of SI).

The figures allow to see differences between technologies (generators) and markets (onshore/offshore). Looking at the relative importance of the components within each plant, the nacelles with direct drive generators have a higher impact share compared to the geared ones. In the context of this study a comparative assessment on a mere component level (e.g. direct drive generator versus geared) cannot be done since system equivalency between the two components is not established. However, product developers can use the results to better understand the environmental profile of alternative technologies and can combine results from design to those from service in order to minimize the environmental impacts from the whole life cycle. Across the two markets differences can be seen in terms of the relevant component contributions. Monopiles and cables are the most impactful for offshore plants compared to the tower which dominates the component impacts onshore. The impacts from components are further discussed in Section 4 in relation to the corresponding materials in them. 


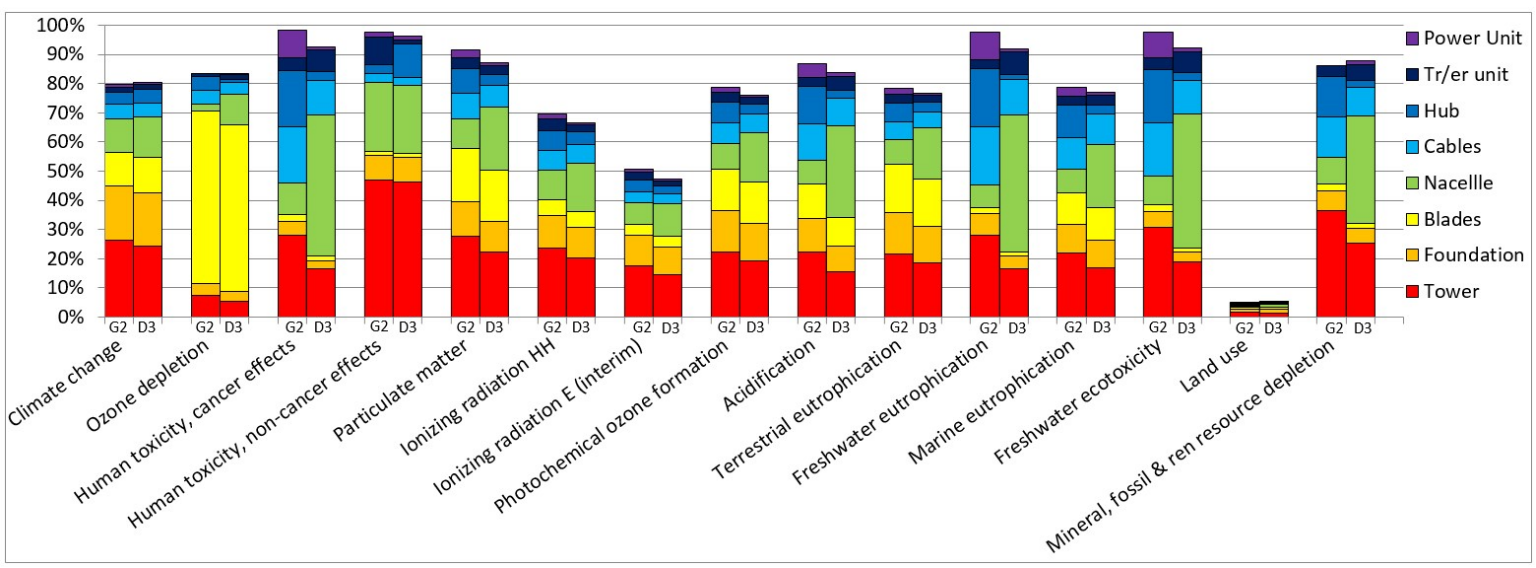

Figure 5. Contribution (\%) of 'Materials' to life cycle impacts and relative contribution of components-onshore

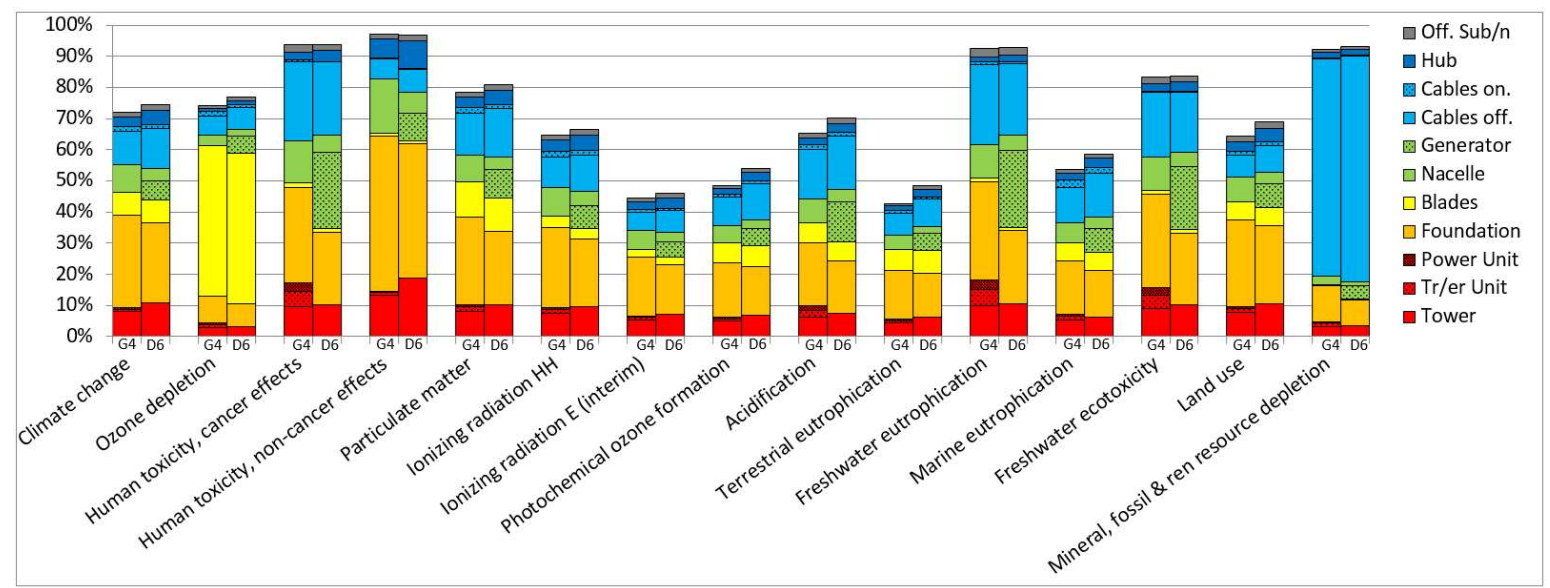

Figure 6. Contribution (\%) of 'Materials' to life cycle impacts and relative contribution of components-offshore

\subsection{Relevant environmental impacts beyond climate change}

Even though 'materials' is the most relevant life cycle stage across impact categories, distinguishing the most environmentally relevant components remains a strenuous task. Figures 5 and 6 show that relevant importance of the plant components changes from one impact category to another as it can explicitly be observed for the case of the blades.

To identify which environmental impacts are most relevant, Figure 7 shows the results from modelling the impacts at an endpoint level. This view allows to see that climate change might be the most important but is not the only relevant impact. For human health respiratory inorganics (particulate matter) and toxic impacts are also worth considering. The latter is in line with Laurent et al. who argue that shifting from a fossils-based European mix to wind power significantly reduces carbon footprint but might leave the 
human toxicity impacts at the same or even higher level [69]. The systems' contribution to ecosystems damages are available in Figure S1 of SI.

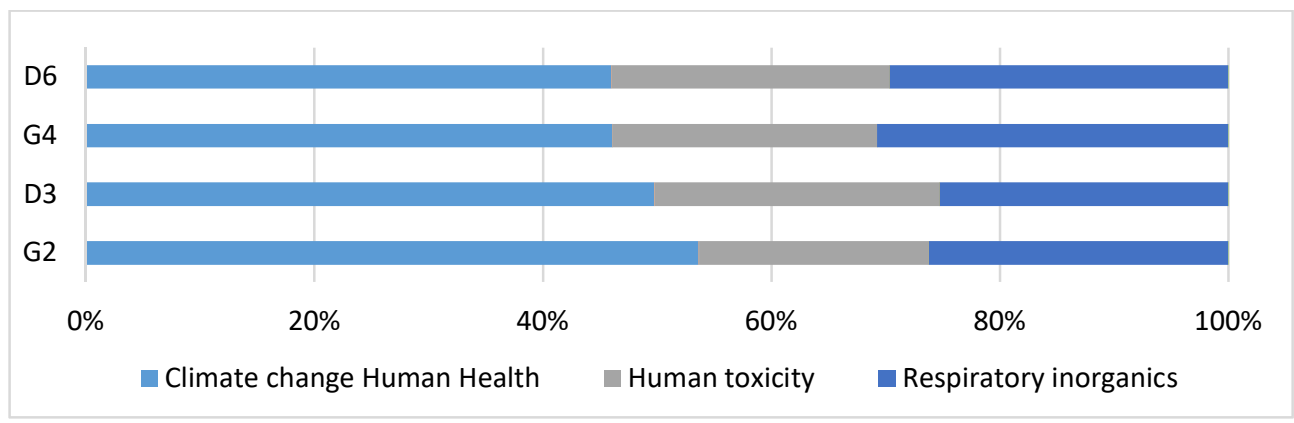

Figure 7. Relative results per impact category for damages to human health

\section{Using LCA results in decision making}

\subsection{Selecting environmental KPIs}

To initiate environmental improvements decision makers need to choose criteria and set corresponding targets based on KPIs e.g. for minimisation of carbon footprint or toxicity-related impacts. However, choosing the environmentally most relevant KPI based on the LCA results can be a challenge. For instance, different impact categories come with different uncertainties. Indicatively the Monte Carlo analyses for quantifying the uncertainty due to inventory data in D3 plant (representative for all plants) resulted to a coefficient of variation $6 \%$ for climate change, $12 \%$ for respiratory inorganics and more than $200 \%$ for non-carcinogenic toxicity (Figures S2 of SI). On top, Figure 7 includes methodological biases since uncertainties from the impact assessment phase as stated in section 2.2 are not accounted for. Challenges are not only due to methodological uncertainties but also due to exogenous factors such as policy and legislation. For example, climate change is in political focus which gives an incentive to use carbon footprint as a KPI. In addition, some impacts can potentially be monitored within parallel initiatives, e.g. SWP complies with European legislation in relation to hazardous substances and also has internal standards in relation to declarable substances [70]. Although they both deal with the issue of toxicity, such initiatives/tools have a different scope than LCA and can only be regarded as complementary.

In the context of this research, although all impact categories were assessed, environmental target setting was based on climate change. This choice rather than optimizing overall environmental performance it aimed to operationalize LCA in the applied setting of SWP. It also addressed the need SWP stakeholders expressed for a balance between scientific robustness and simplicity. Climate change (i) was easier to communicate due to the current political focus, (ii) was proved adequate for identifying overall hotspots. Indeed, the inventory items contributing more than $1 \%$ to climate change are given in Figure 8 . Altogether these contribute more than $90 \%$ to the total climate change impact. The same items are also the ones mostly (> 75\%) contributing to each of all other environmental impact categories as well (see Tables S2 and $\mathrm{S} 3$ of $\mathrm{SI})$. 
Table 5. Inventory items that together contribute more than $75 \%$ in all the assessed environmental impact categories. Contribution (\%) to climate change (CC) is given. The EoL is expressed as percentage of the other life cycle stages.

\begin{tabular}{|l|l|c|c|}
\hline LC Stage & \multicolumn{1}{|c|}{ Inventory items } & \multicolumn{2}{|c|}{ \% contribution to CC } \\
\hline \multirow{5}{*}{ Materials } & & $\begin{array}{c}\text { Onshore } \\
\text { G2-D3 }\end{array}$ & $\begin{array}{c}\text { Offshore } \\
\text { G4-D6 }\end{array}$ \\
\cline { 2 - 4 } & Tower & $26-24 \%$ & $9-11 \%$ \\
\cline { 2 - 4 } & Foundation & $18 \%$ & $29 \%$ \\
\cline { 2 - 4 } & Nacelle & $11 \%-13 \%$ & $9-10 \%$ \\
\cline { 2 - 4 } & Blades & $11 \%-12 \%$ & $7 \%$ \\
\cline { 2 - 4 } & On/re cables & $5 \%$ & $2-1 \%$ \\
\cline { 2 - 4 } & Off/re cables & - & $10-13 \%$ \\
\cline { 2 - 4 } & Hub & $4 \%-5 \%$ & $3-5 \%$ \\
\cline { 2 - 4 } & Transformer unit & $1 \%$ & $<1 \%$ \\
\cline { 2 - 4 } & Power unit & $1 \%$ & $<1 \%$ \\
\hline \multirow{5}{*}{ Manufacturing } & Tower & $2-1 \%$ & $<1 \%$ \\
\cline { 2 - 4 } & Nacelle \& hub & $2 \%$ & $1 \%$ \\
\cline { 2 - 4 } & Cables & $<1 \%$ & $2 \%$ \\
\cline { 2 - 4 } & Waste mgmt. & $<1 \%$ & $1 \%-2 \%$ \\
\hline \multirow{5}{*}{ Installation } & Gravel road & $4 \%-3 \%$ & - \\
\cline { 2 - 4 } & Cable laying & $1 \%$ & $3 \%$ \\
\cline { 2 - 4 } & Vessel use & - & $4 \%$ \\
\cline { 2 - 4 } & Foundation setting & $<1 \%$ & $4 \%-3 \%$ \\
\hline \multirow{5}{*}{ Operation } & Service & $<1 \%$ & $1 \%$ \\
\hline \multirow{5}{*}{ Eismantling } & Vessel use & - & $3 \%$ \\
\cline { 2 - 4 } & Foundation removal & $<1 \%$ & $3 \%-2 \%$ \\
\cline { 2 - 4 } & Cable removal & $<1 \%$ & $1 \%$ \\
\hline & Tower recycling & $-(19-18 \%)$ & $-(6 \%-8 \%)$ \\
\cline { 2 - 4 } & Foundation recycling & $-4 \%$ & $-(11-10 \%)$ \\
\cline { 2 - 4 } & Nacelle recycling & $-(6 \%-5 \%)$ & $-4 \%$ \\
\hline \multirow{5}{*}{ End of Life } & & \\
& & &
\end{tabular}

Table 5 also reveals the issue of shared responsibility (and therefore accountability) for the corresponding impacts beyond organizational boundaries across the value chain. Regarding 'materials', which is the main contributor to the systems' life cycle, each of the plants' components requires decisions from multiple manufacturers. For example, all design and manufacturing of blades occurs within SWP with several company internal stakeholder groups contributing to product development. For the nacelles, design and assembly occurs in SWP but all manufacturing occurs at suppliers. Foundations and towers, even though designed by SWP, are accordingly manufactured and delivered to the power plant site by regiondependent suppliers. Responsibility for the cables, particularly relevant to offshore plants as seen in Figure 6 , lies beyond SWP. All components further rely on market-dependent volatile supply chains. External bodies such as regulators or peers also affect the entire system.

The rest of this section uses climate change as KPI and addresses the second aim of this paper (see Section 1) which is to exemplify how LCA can inform the product development and system planning if integrated.

\subsection{Materials- LCA can be used for eco-design and product development}

Shifting the focus from components to the materials that compose them, Figure 8 shows the relationship between the consumed quantity and the corresponding impact for the materials in the infrastructure of the onshore D3 and the offshore D6 plants. The materials presented cover more than $98 \%$ of 
infrastructure weight (i.e. turbines, foundations substations, cables). This view allows seeing whether the impact is driven by the type of material or the quantity used, e.g. in the D3 plant epoxy and concrete have similar impact. For concrete this is driven from the weight while for epoxy it is due to the impact density of the material (epoxy is 48 times more impactful per kg compared to concrete). This view enlightens material improvement potentials and can be used by different engineering groups across the product development e.g. similar analysis has been done to suggest meaningful target setting for blade design [71].

Figure 8 shows the importance of the metals found mostly in towers, cables and monopiles. The figure also shows that materials used for the blades are impact dense. The results can set the focus to investigating alternative advanced structural designs, e.g. comparing between monopiles, tripods, jackets and floating offshore foundations as discussed in [59]. Regarding the vast concrete quantities the results direct the research to concrete recycling technologies and an optimization of these since, based on LCA studies, they currently do not provide net environmental benefits [72].

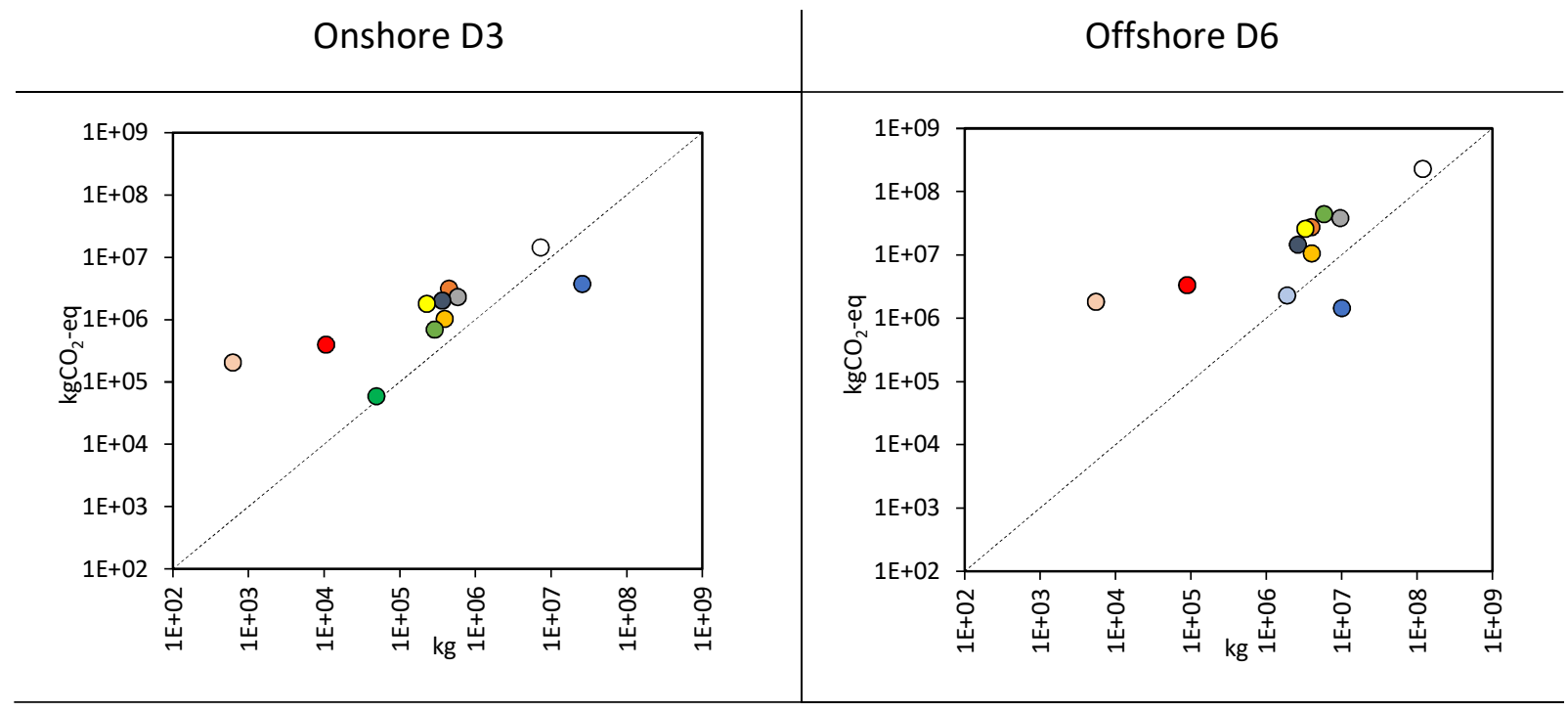

O Concrete OSteel OEpoxy O Iron O Copper OGlass fibre O Polymers OAluminium O Lubricants O Lead O REO OTeflon

Figure 8. Material consumption and corresponding GHG emissions for the materials used in infrastructure (turbines, foundations, substations, cabling). Materials at the left of the diagonal imply a ratio $\mathrm{kgCO}-\mathrm{eq} / \mathrm{kg}>1$. Values are given per plant and not per FU

\subsection{Manufacturing - LCA can inform supply chain management and collaborative action}

The LCA results provided insights for the impacts related to supply chain. Alternative suppliers were mapped and environmental impacts due to transport and partly due to production at their site were calculated. Towards a collaborative supply chain management suggested by literature [73] environmental actions can in the future be initiated with suppliers both in terms of data collection, target setting and compliance with company requirements. So far 58 SWP suppliers have committed to such a program [74]. 


\section{Bonou A, Laurent A, Olsen SI (2016) Life cycle assessment of onshore and offshore wind energy-from theory to application. Appl Energy 180:327-337. doi: 10.1016/j.apenergy.2016.07.058}

The near-negligible contribution of the manufacturing in SWP, i.e. less than $1 \%$ of the life cycle impact (see also section 4.2), puts in perspective the importance of broadening the scope of environmental initiatives beyond organizational boundaries where typically companies set targets. Currently SWP has the strategic target to lower the manufacturing impact by $50 \%$ by 2020 [75]. This would lead to less than $0.5 \%$ reduction of the total impact from the life cycle. Therefore, conventional environmental target setting risks setting targets that have little influence on the overall life cycle impact.

\subsection{Installation/Operation - environmental improvement is synergetic to logistics}

LCA results for installation and service show that environmental impacts are primarily related to transport. Environmental improvement is therefore synergetic to optimization of logistics, which has high priority particularly to the offshore plants due to the high costs [76]. Within SWP when planning such operations, LCA results were used to inform about the environmental relevance of alternative business cases i.e. alternative modes for transporting the crew to the site. Across organisations, inventory data collection for the LCA study has helped the company to map all related operations. Indicatively SWP has decision power in only 5 out of 14 identified offshore installation activities. The corresponding LCA results have been used to explore sustainability related targets together with other stakeholders such as energy service companies.

\subsection{End of life - a significant yet most uncertain life cycle stage}

The EoL is currently outside the operational boundaries of SWP and its inclusion in ecodesign initiatives is challenged by uncertainties on a temporal, technological and business level such as the long lifetime, the lack of treatment technologies (e.g. for the blades) and the lack of established take-back systems [47]. Therefore, LCA results have not had any direct intraorganisational implications. Rather they have been used to initiate discussions with project managers and engineers within SWP in investigating the transition towards more circular business models such as the ones established for waste electronics in the context of extended producer responsibility [77].

\section{Conclusions and further research}

The objectives of this applied research were (i) to provide an understanding of the environmental impacts of state of the art wind power technologies (ii) to showcase how LCA results can inform technology and system planning. The first objective contributes to a currently small pool of studies addressing life cycle environmental impacts of wind turbines, especially off-shore. The second objective addresses the questions of how LCA results can feed into planning and decisions making in real life applications of wind energy systems.

Four representative European power plants onshore and offshore with 2015 state of the art technology provided by Siemens Wind Power were assessed. The energy payback time was found to be less than 1 year for all plants. The $\mathrm{GHG}$ emissions are less than $7 \mathrm{~g} \mathrm{CO}_{2}$-eq/ $\mathrm{kWh}$ for onshore and $11 \mathrm{~g} \mathrm{CO}_{2}$-eq/ $\mathrm{kWh}$ for offshore.

The higher impact of offshore is mainly due to more material requirements for capital equipment (monopiles, cables). Offshore also requires more resources (fuel and transport) for installation and 


\section{Bonou A, Laurent A, Olsen SI (2016) Life cycle assessment of onshore and offshore wind energy-from}

theory to application. Appl Energy 180:327-337. doi: 10.1016/j.apenergy.2016.07.058

maintenance. Overall material and energy requirements do not counterbalance the benefits of higher energy output compared to the onshore market. In both markets the bigger turbines with more advanced direct drive generator technology perform better than the smaller geared ones.

In all plants capital infrastructure accounts more than $79 \%$ and $70 \%$ in climate change impacts onshore and offshore respectively. In the manufacturing stage most of the impacts are due to operations at suppliers' sites while the impacts due to operations at SWP do not exceed $1 \%$ of the impacts. In the installation stage impacts are shared among supply chain actors, while the EoL stage could lead to environmental savings reaching $20-30 \%$ due to high recycling potentials. The system's performance is highly sensitive to wind speed, life time and efficiency. Climate change was a good KPI for overall hotspot identification. However, end point results showed that the assessed systems have also significant contribution to human toxicity and impacts from respiratory inorganics.

The usefulness of the LCA results was discussed on the basis of real life examples from across the life cycle of the plants. LCA can be used in product development for eco-design applications e.g. for understanding the environmental impacts of materials, therefore supporting the selection of more sustainable alternatives. In manufacturing, LCA can be used for more sustainable supply chain management. Regarding installation, environmental improvement is synergetic to optimization of logistics. End of life is a significant yet most uncertain life cycle stage. The potential savings from recycling at the EoL could feed the discussion around transitioning to more circular business models. The approach followed during the analysis can give a more systemic perspective to wind power technology planning in terms of environmental management [78]. The results also highlight the shared responsibility across multiple stakeholders. Extending across organizations collaborative efforts can be initiated for environmental management across the value chain, e.g. through data sharing, increased transparency and development of common environmental KPIs.

In light of these findings, the study has however revealed needs for future research:

- The EOL is the second more crucial and the most uncertain part of the system. Lack of data around existing end of life treatment technologies, and lack of recycling technologies for the composite materials such as the blades constitute a future research focus point. Consequently, there is a need for investigating alternative business models within the context of circular economy giving evidence of life cycle thinking integration into planning of future systems and technologies

- Extending the boundaries and the scope would enhance the understanding of true life cycle emissions of wind power, e.g. Wiedmann et al. show that hybrid and I/O approaches could double the assessed impact [67]. Also the impacts due to backup systems and energy storage requirements that the current studies exclude from the system boundaries should also be investigated. Such aspects can also be accounted for in cconsequential LCAs which aim to capture the impacts of renewable energy policy implementation.

\section{Acknowledgements}

This research has been carried out in the context of an industrial Ph.D. project funded by the Corporate Technology department of Siemens AG and the Innovation Fund Denmark. The opportunity and support 


\section{Bonou A, Laurent A, Olsen SI (2016) Life cycle assessment of onshore and offshore wind energy-from}

theory to application. Appl Energy 180:327-337. doi: 10.1016/j.apenergy.2016.07.058

from Siemens Wind Power is gratefully acknowledged, particularly from Tine H. Jørgensen, Esben Nielsen and Kend Knudsen.

\section{References}

[1] IEA. World Energy Outlook 2014. Paris: OECD/IEA; 2014. doi:10.1787/weo-2014-en.

[2] REN21. RENEWABLES 2015 GLOBAL STATUS REPORT. Paris: 2015.

[3] Corbetta G, Ho A, Pineda I. Wind energy scenarios for 2030. 2015.

[4] EWEA. Wind in Power, 2013 statistics 2014.

http://www.ewea.org/fileadmin/files/library/publications/statistics/EWEA_Annual_Statistics_2013.pdf.

[5] Scott Semken R, Polikarpova M, Röyttä P, Alexandrova J, Pyrhönen J, Nerg J, et al. Direct-drive permanent magnet generators for high-power wind turbines: benefits and limiting factors. IET Renew Power Gener 2012;6:1. doi:10.1049/iet-rpg.2010.0191.

[6] Schlipf D, Schlipf DJ, Kühn M. Nonlinear model predictive control of wind turbines using LIDAR. Wind Energy 2013;16:1107-29. doi:10.1002/we.1533.

[7] Gadad S, Deka PC. Offshore wind power resource assessment using Oceansat-2 scatterometer data at a regional scale. Appl Energy 2016;176:157-70. doi:http://dx.doi.org/10.1016/j.apenergy.2016.05.046.

[8] Zhao H, Wu Q, Hu S, Xu H, Rasmussen CN. Review of energy storage system for wind power integration support. Appl Energy 2015;137:545-53. doi:10.1016/j.apenergy.2014.04.103.

[9] De Jonghe C, Delarue E, Belmans R, D'haeseleer W. Determining optimal electricity technology mix with high level of wind power penetration. Appl Energy 2011;88:2231-8. doi:10.1016/j.apenergy.2010.12.046.

[10] Shen Z, Ritter M. Forecasting volatility of wind power production. Appl Energy 2016;176:295-308. doi:http://dx.doi.org/10.1016/j.apenergy.2016.05.071.

[11] Exizidis L, Kazempour SJ, Pinson P, de Greve Z, Vallée F. Sharing wind power forecasts in electricity markets: A numerical analysis. Appl Energy 2016;176:65-73. doi:http://dx.doi.org/10.1016/j.apenergy.2016.05.052.

[12] Moura PS, de Almeida AT. The role of demand-side management in the grid integration of wind power. Appl Energy 2010;87:2581-8. doi:10.1016/j.apenergy.2010.03.019.

[13] Weber A, Beckers T, Behr P, Bieschke N, Fehner S, Von Hirschhausen C. Long - term Power System Planning Conceptual Issues and Selected Evidence from Europe. Berlin: 2013.

[14] Thygesen J, Agarwal A. Key criteria for sustainable wind energy planning-lessons from an institutional perspective on the impact assessment literature. Renew Sustain Energy Rev 2014;39:1012-23. doi:10.1016/j.rser.2014.07.173.

[15] Finnveden G, Nilsson M, Johansson J, Persson $\AA$, Moberg $\AA$, Carlsson T. Strategic environmental assessment methodologies-applications within the energy sector. Environ Impact Assess Rev 2003;23:91-123. doi:10.1016/S0195-9255(02)00089-6.

[16] Björklund A. Life cycle assessment as an analytical tool in strategic environmental assessment. Lessons learned from a case study on municipal energy planning in Sweden. Environ Impact Assess Rev 2012;32:82-7. doi:10.1016/j.eiar.2011.04.001.

[17] EC-JRC. International Reference Life Cycle Data System (ILCD) Handbook - General guide for Life Cycle Assessment Detailed guidance. 1st ed. Luxembourg: Publications Office of the European Union; 2010. doi:10.2788/38479.

[18] IPCC. Summary for Policymakers. In: IPCC Special Report on Renewable Energy Sources and Climate Change Mitigation. Cambridge, United Kingdom and New York, NY, USA: Cambridge University Press; 2011.

[19] Laurent A, Espinosa N. Environmental impacts of electricity generation at global, regional and national scales in 19802011: what can we learn for future energy planning? Energy Environ Sci 2015;8:689-701. doi:10.1039/C4EE03832K.

[20] Lund H, Mathiesen BV, Christensen P, Schmidt JH. Energy system analysis of marginal electricity supply in consequential LCA. Int J Life Cycle Assess 2010;15:260-71. doi:10.1007/s11367-010-0164-7.

[21] Foidart F, Oliver-Solá J, Gasol CM, Gabarrell X, Rieradevall J. How important are current energy mix choices on future sustainability? Case study: Belgium and Spain-projections towards 2020-2030. Energy Policy 2010;38:5028-37. doi:10.1016/j.enpol.2010.04.028.

[22] Rodríguez MAR, Cespón MF, Ruyck J De, Guevara VSO, Verma VK. Life cycle modeling of energy matrix scenarios, Belgian power and partial heat mixes as case study. Appl Energy 2013;107:329-37. doi:http://dx.doi.org/10.1016/j.apenergy.2013.02.052.

[23] Berrill P, Arvesen A, Scholz Y, Gils HC, Hertwich EG. Environmental impacts of high penetration renewable energy scenarios for Europe. Environ Res Lett 2016;11:014012. doi:10.1088/1748-9326/11/1/014012.

[24] Cherubini F, Ulgiati S. Crop residues as raw materials for biorefinery systems - A $\{$ LCA $\}$ case study. Appl Energy 2010;87:47-57. doi:http://dx.doi.org/10.1016/j.apenergy.2009.08.024.

[25] Collet P, Hélias A, Lardon L, Steyer J-P, Bernard O. Recommendations for Life Cycle Assessment of algal fuels. Appl Energy 2015;154:1089-102. doi:http://dx.doi.org/10.1016/j.apenergy.2015.03.056. 
[26] Hamelin L, Naroznova I, Wenzel H. Environmental consequences of different carbon alternatives for increased manurebased biogas. Appl Energy 2014;114:774-82. doi:http://dx.doi.org/10.1016/j.apenergy.2013.09.033.

[27] Whittaker C, Borrion AL, Newnes L, McManus M. The renewable energy directive and cereal residues. Appl Energy 2014;122:207-15. doi:http://dx.doi.org/10.1016/j.apenergy.2014.01.091.

[28] Hou G, Sun H, Jiang Z, Pan Z, Wang Y, Zhang X, et al. Life cycle assessment of grid-connected photovoltaic power generation from crystalline silicon solar modules in China. Appl Energy 2016;164:882-90. doi:http://dx.doi.org/10.1016/j.apenergy.2015.11.023.

[29] Xue B, Ma Z, Geng Y, Heck P, Ren W, Tobias M, et al. A life cycle co-benefits assessment of wind power in China. Renew Sustain Energy Rev 2015;41:338-46. doi:10.1016/j.rser.2014.08.056.

[30] Lenzen M, Wachsmann U. Wind turbines in Brazil and Germany: an example of geographical variability in life-cycle assessment. Appl Energy 2004;77:119-30. doi:10.1016/S0306-2619(03)00105-3.

[31] Martínez E, Sanz F, Pellegrini S, Jiménez E, Blanco J. Life cycle assessment of a multi-megawatt wind turbine. Renew Energy 2009;34:667-73. doi:10.1016/j.renene.2008.05.020.

[32] Haapala KR, Prempreeda P. Comparative life cycle assessment of $2.0 \mathrm{MW}$ wind turbines. Int J Sustain Manuf 2014;3:170. doi:10.1504/IJSM.2014.062496.

[33] Mithraratne N. Roof-top wind turbines for microgeneration in urban houses in New Zealand. Energy Build 2009;41:1013-8. doi:10.1016/j.enbuild.2009.05.003.

[34] Nugent D, Sovacool BK. Assessing the lifecycle greenhouse gas emissions from solar PV and wind energy: A critical meta-survey. Energy Policy 2014;65:229-44. doi:10.1016/j.enpol.2013.10.048.

[35] Arvesen A, Hertwich EG. Assessing the life cycle environmental impacts of wind power: A review of present knowledge and research needs. Renew Sustain Energy Rev 2012;16:5994-6006. doi:10.1016/j.rser.2012.06.023.

[36] BTM Consult ApS. World energy market update 2015. 2015.

[37] Corbetta G, Mbistrova A, Ho A, Guillet J, Pineda I. The European offshore wind industry - key trends and statistics 2014. 2014.

[38] ISO. ISO 14040:2006. Environmental management-Life cycle assessment-Principles and framework. 2006.

[39] Bilgili M, Yasar A, Simsek E. Offshore wind power development in Europe and its comparison with onshore counterpart. Renew Sustain Energy Rev 2011;15:905-15. doi:10.1016/j.rser.2010.11.006.

[40] Esteban M. Current developments and future prospects of offshore wind and ocean energy. Appl Energy 2012;90.

[41] Rybicka J, Tiwari A, Leeke GA. Technology readiness level assessment of composites recycling technologies. J Clean Prod 2015. doi:10.1016/j.jclepro.2015.08.104.

[42] Pickering SJ. Recycling technologies for thermoset composite materials-current status. Compos Part A Appl Sci Manuf 2006;37:1206-15. doi:10.1016/j.compositesa.2005.05.030.

[43] WEC. World Energy Scenarios: Composing energy futures to 2050. London: 2013.

[44] Grimes S, Donaldson J, Cebrian Gomez G. Report on the Environmental Benefits of Recycling. London: 2008.

[45] Walters RN, Hackett SM, Lyon RE. Heats of combustion of high temperature polymers. Fire Mater 2000;24:245-52. doi:10.1002/1099-1018(200009/10)24:5<245::AID-FAM744>3.0.CO;2-7.

[46] Weidema BP, Bauer C, Hischier R, Mutel C, Nemecek T, Reinhard J, et al. The ecoinvent database: Overview and methodology, Data quality guideline for the ecoinvent database version 32013.

[47] Ortegon K. Preparing for end of service life of wind turbines. J Clean Prod 2013;39.

[48] Job S. Recycling glass fibre reinforced composites - history and progress. Reinf Plast 2013;57:19-23. doi:10.1016/S0034-3617(13)70151-6.

[49] GARC. Global Aluminium Recycling: A Cornerstone of Sustainable Development. 2009.

[50] Schlesinger ME. Aluminum recycling. Taylor \& Francis; 2006.

[51] Dahlbo H, Bachér J, Lähtinen K, Jouttijärvi T, Suoheimo P, Mattila T, et al. Construction and demolition waste management - a holistic evaluation of environmental performance. J Clean Prod 2015. doi:10.1016/j.jclepro.2015.02.073.

[52] Forster P, Ramaswamy V, Artaxo P, Berntsen T, Betts R, Fahey D, et al. Changes in atmospheric constituents and in radiative forcing. In: Solomon S, Qin D, Manning M, Chen Z, Marquis M, Averyt K, et al., editors. Clim. Chang. 2007 Phys. Sci. basis. Contrib. Work. Gr. I to Fourth Assess. Rep. Intergov. Panel Clim. Chang., Cambridge: Cambridge University Press; 2007.

[53] Evans A, Strezov V, Evans TJ. Assessment of sustainability indicators for renewable energy technologies. Renew Sustain Energy Rev 2009;13:1082-8. doi:10.1016/j.rser.2008.03.008.

[54] Althaus H-J, Bauer C, Doka G, Dones R, Hischier R, Hellweg S, et al. Implementation of Life Cycle Impact Assessment Methods Data v2.0. Dübendorf: 2007.

[55] Hauschild MZ, Goedkoop M, Guinée J, Heijungs R, Huijbregts M, Jolliet O, et al. Identifying best existing practice for characterization modeling in life cycle impact assessment. Int J Life Cycle Assess 2013;18:683-97. doi:10.1007/s11367012-0489-5.

[56] Jolliet O, Margni M, Charles R, Humbert S, Payet J, Rebitzer G, et al. IMPACT 2002+: A new life cycle impact assessment 
methodology. Int J Life Cycle Assess 2003;8:324-30. doi:10.1007/BF02978505.

[57] Hauschild MZ. Assessing environmental impacts in a life-cycle perspective. Environ Sci Technol 2005;39.

[58] Treyer K, Bauer C. Life cycle inventories of electricity generation and power supply in version 3 of the ecoinvent database-part I: electricity generation. Int J Life Cycle Assess 2013:1-19. doi:10.1007/s11367-013-0665-2.

[59] Wiser R, Yang Z, Hand M, Hohmeyer O, Eld DI, Jensen PH, et al. Wind Energy. In IPCC Special Report on Renewable Energy Sources and Climate Change Mitigation. In: Edenhofer O, Pichs-Madruga R, Sokona Y, Seyboth K, Matschoss P, Kadner S, et al., editors., Cambridge, United Kingdom and New York, NY, USA: Cambridge University Press; 2011.

[60] Tremeac B, Meunier F. Life cycle analysis of 4.5MW and 250W wind turbines. Renew Sustain Energy Rev 2009;13:2104-10. doi:10.1016/j.rser.2009.01.001.

[61] Lenzen M, Munksgaard J. Energy and CO2 life-cycle analyses of wind turbines-review and applications. Renew Energy 2002;26:339-62. doi:10.1016/S0960-1481(01)00145-8.

[62] Caduff M, Huijbregts MAJ, Althaus H-J, Koehler A, Hellweg S. Wind Power Electricity: The Bigger the Turbine, The Greener the Electricity? Environ Sci Technol 2012;46:4725-33. doi:10.1021/es204108n.

[63] Owens E, Chapman S. Valuing the Greenhouse Gas Emissions from Wind Power. Int J Energy Eng 2013;3:41-54. doi:10.5963/IJEE0302006.

[64] Martínez E, Sanz F, Pellegrini S, Jiménez E, Blanco J. Life-cycle assessment of a 2-MW rated power wind turbine: CML method. Int J Life Cycle Assess 2008;14:52-63. doi:10.1007/s11367-008-0033-9.

[65] Garrett P, Rønde K. Life cycle assessment of wind power: comprehensive results from a state-of-the-art approach. Int J Life Cycle Assess 2013;18:37-48. doi:10.1007/s11367-012-0445-4.

[66] Dolan SL. Life Cycle Greenhouse Gas Emissions of Utility-Scale Wind Power. J Ind Ecol 2012;16.

[67] Wiedmann TO, Suh S, Feng K, Lenzen M, Acquaye A, Scott K, et al. Application of hybrid life cycle approaches to emerging energy technologies--the case of wind power in the UK. Environ Sci Technol 2011;45:5900-7. doi:10.1021/es2007287.

[68] Guezuraga B, Zauner R, Pölz W. Life cycle assessment of two different $2 \mathrm{MW}$ class wind turbines. Renew Energy 2012;37:37-44. doi:10.1016/j.renene.2011.05.008.

[69] Laurent $\mathrm{A}$, Olsen $\mathrm{SI}$, Hauschild MZ. Limitations of carbon footprint as indicator of environmental sustainability. Environ Sci Technol 2012;46:4100-8. doi:10.1021/es204163f.

[70] Siemens AG. Product-related environmental protection 2016. http://w5.siemens.com/cms/supply-chainmanagement/en/supplier-at-siemens/basic-information/environment/product/pages/stewardship.aspx.

[71] Bonou A, Olsen SI, Hauschild MZ. Introducing life cycle thinking in product development - A case from Siemens Wind Power. CIRP Ann - Manuf Technol 2015;64:45-8. doi:10.1016/j.cirp.2015.04.053.

[72] Butera S. Environmental Impacts Assessment of Recycling of Construction and Demolition Waste. Technical University of Denmark, 2015.

[73] Attaran M, Attaran S. Collaborative supply chain management. Bus Process Manag J 2007;13:390-404. doi:10.1108/14637150710752308.

[74] Uebelhoer K, Guder J, Holst JC, Heftrich B. Greenhouse Gas management along the supply chain at Siemens. LCM 2013, 2013.

[75] Siemens AG. Siemens to be climate neutral by 20302016. http://www.siemens.com/press/en/feature/2015/corporate/2015-09-co2-neutral.php?content[]=Corp.

[76] Timilsina GR, Cornelis van Kooten G, Narbel PA. Global wind power development: Economics and policies. Energy Policy 2013;61:642-52. doi:10.1016/j.enpol.2013.06.062.

[77] Cucchiella F, D’Adamo I, Lenny Koh SC, Rosa P. Recycling of WEEEs: An economic assessment of present and future ewaste streams. Renew Sustain Energy Rev 2015;51:263-72. doi:10.1016/j.rser.2015.06.010.

[78] Bonou A, Skelton K, Olsen SI. Ecodesign framework for developing wind turbines. J Clean Prod 2016. doi:10.1016/j.jclepro.2016.02.093. 
Bonou A, Laurent A, Olsen SI (2016) Life cycle assessment of onshore and offshore wind energy-from theory to application. Appl Energy 180:327-337. doi: 10.1016/j.apenergy.2016.07.058

Table S1. Inventory activities and primary data sources grouped per life cycle stage.

Quality evaluation on 3 scale basis (Q). Market specification: ( $n$ : for onshore, f: for offshore, n/f: for both). Data type: material, $\square$ fuel/energy $\quad \square$ transport $\square$ waste

LCS Description

\begin{tabular}{|l|l|l}
$n / f$ & Nacelle \\
\hline$n / f$ & Hub \\
\hline
\end{tabular}

n/f Tower

$\mathrm{n} / \mathrm{f}$ PU /TU

\begin{tabular}{l|l|l}
$\mathrm{n} / \mathrm{f}$ & $\mathrm{PU} / \mathrm{TU}$ \\
$\mathrm{n} / \mathrm{f}$ & Blades (BOM/R\&D)
\end{tabular}

$n$ Foundation

$\mathrm{n} / \mathrm{f}$ Onshore Cables to grid

$\backsim$ n/f Onshore substation

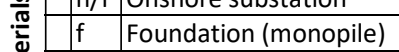

$\underset{\pi}{*} \mathrm{f}$ Offshore cables

\begin{tabular}{|ll}
$\mathrm{f}$ & Offshore cables \\
\hline $\mathrm{f}$ & Offshore substations
\end{tabular}

n/f Resources in-house

$\mathrm{n} / \mathrm{f}$ Resources in main suppliers

n Resources for tower man.

$\mathrm{n} / \mathrm{f}$ Resources for transformer man.

wo f Resources for off. cable man.

Resources for monopile man.

$\mathrm{n} / \mathrm{f}$ Transport from suppliers to SWP

n/f Transport during man.

$\mathrm{n} / \mathrm{f}$ Waste from SWP man.

$\mathrm{n} / \mathrm{f}$ Waste from cable man.

Gravel road

$\mathrm{n} / \mathrm{f}$ Transport equipment

Resources at site

Primary inventory data

2013 Bill of Materials (BOM) from the company's enterprise resource planning (ERP) system. Component subparts characterized as of their main material, e.g. 'steel-S355' in collaboration with product development SWP engineers. Material composition identified for $97-99 \%$ of component weight. The rest has been allocated to the identified materials proportionally, e.g. for the D3 nacelle, 753 out of 1061 subparts that cover $99,9 \%$ of the nacelle weight have been characterized.

Same identification as above. Data cover BOM and all R\&D consumption from 3 manufacturing facilities. Allocation per blade based on weight or surface Calculation of reinforced concrete requirements based on standard site of certain friction angle, sand density and buoyancy

Cable type and length identified for a typical $19 \times 3.2$ onshore project. Assumed the same in all plants. Material specifications for cables from supplier Data for raw materials in onshore substation on the basis of an off-shore project. No adjustment for the smaller MW output for an onshore plant Data for type and quality of materials, from a reference project

Cable materials identified from reference project. Offshore distances are based on expert judgment based on sales data

Material data from reference project. Transformer data from supplier's EPD. Data scaled for $2 \mathrm{pc}$ for 4.0 and $2.5 \mathrm{pc}$ for 6.0

Resources for manufacturing nacelles, hubs and blades (including R\&D). Data collected from 3 manufacturing sites in DK. Major offices in DK are included

Supplier data for canopy (nacelle) and hub. For cables data are given from supplier for a reference project

Data for energy, waste and direct emissions are delivered by a supplier for a reference project

Data from supplier for reference project

Energy data from average project

Supplier data for energy usage per tonne tower produced

14 Suppliers for the heaviest components, identified for the European projects. Exact distances calculated and extrapolated to the total supplied weight

Blades transported between manufacturing facilities in DK

Waste from manufacturing nacelle and hub and blades (including R\&D waste). Waste data and corresponding treatment from three DK facilities

Specifications for cables from supplier

Amount of gravel for roads and stands on wind farm site

For nacelle, blades, hub, PU: Data from the company's ERP system for all platforms except for 6.0 (was still in development). Life time and reuse rates included

Data per turbine collected from bills for a reference project and from main crane supplier. Assumed same for both plants.

Resources for offshore substation

Resources for preassembly

Resources for monopile

$\mathrm{n} / \mathrm{f}$ Transport of cables to site

n/f Transport from SWP to site

$\mathrm{n} / \mathrm{f}$ Transport of substation to site

includes installation at site for both foundation, platform, topside of substation. Data from reference project

Data covers start of project to commissioning in a 6 month period for a reference project. Same data for both plants

Energy consumption data from reference project

Supplier data for tkm travelled from supplier to site and corresponding transport modes. Also fuel for cable laying

Calculated as an average of predefined reference projects used by in company experts for logistics

Former data for amount of transport for trucks/machinery from a reference project

\begin{tabular}{l|l|l|l|l} 
n & Person transport & size \\
\hline
\end{tabular}

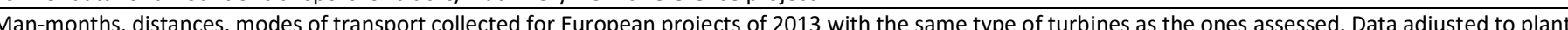
size

Installation Vessel (mobilization, transit to site, return from preassembly, installation at site and at the preassembly port, demobilization)

Transport for offshore installation Person Transport (transfers from hotel vessels to turbines), Hotel Vessel (consumption for technicians' accommodation).

Transport of monopile to site

$\mathrm{n} / \mathrm{f}$ Waste during installation

/f Service materials

$n / f$ Waste from service

$\mathrm{n} / \mathrm{f}$ Transport for maintenance

$\mathrm{f}$ Dismantling of turbine at site

$\vec{b} \mathrm{n} / \mathrm{f}$ Transport to EoL treatment

Fuel consumption from reference project

Only total amount of recyclable waste is known. Data per turbine collected from bills for reference project. Same data for both turbines

Spare parts for large parts based on historical data and conservative technical evaluations. Service materials per platform for annual service

Assumption that service waste is the same as the material input for service

Fuel for technicians' transport based on planned and unplanned service, and transport setup for technicians and parts

Has been estimated as a percentage $(75 \%)$ of resources used during establishment of site

$\mathrm{n} / \mathrm{f}$ EoL treatment of materials

literature data for distances to disposal sites

Recycling rates from reference project within Siemens AG. Data supplemented by literature and confirmed by company expert 
Bonou A, Laurent A, Olsen SI (2016) Life cycle assessment of onshore and offshore wind energy-from theory to application. Appl Energy 180:327-337. doi: 10.1016/j.apenergy.2016.07.058

Table S2. LCA results (impacts/FU) for the onshore wind power plants (the items shown are the ones contributing more than $1 \%$ to climate change)
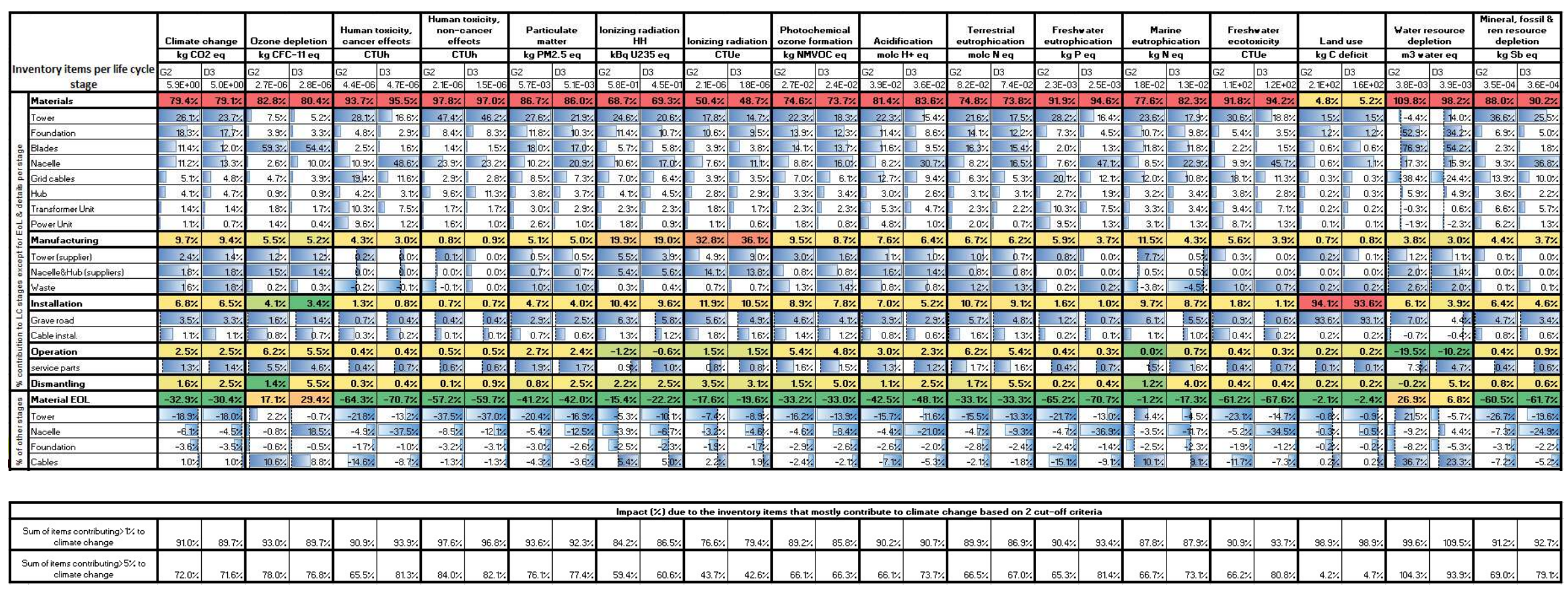
Table S3. LCA results (impacts/FU) for the offshore wind power plants (the items shown are the ones contributing more than1\% to climate change)
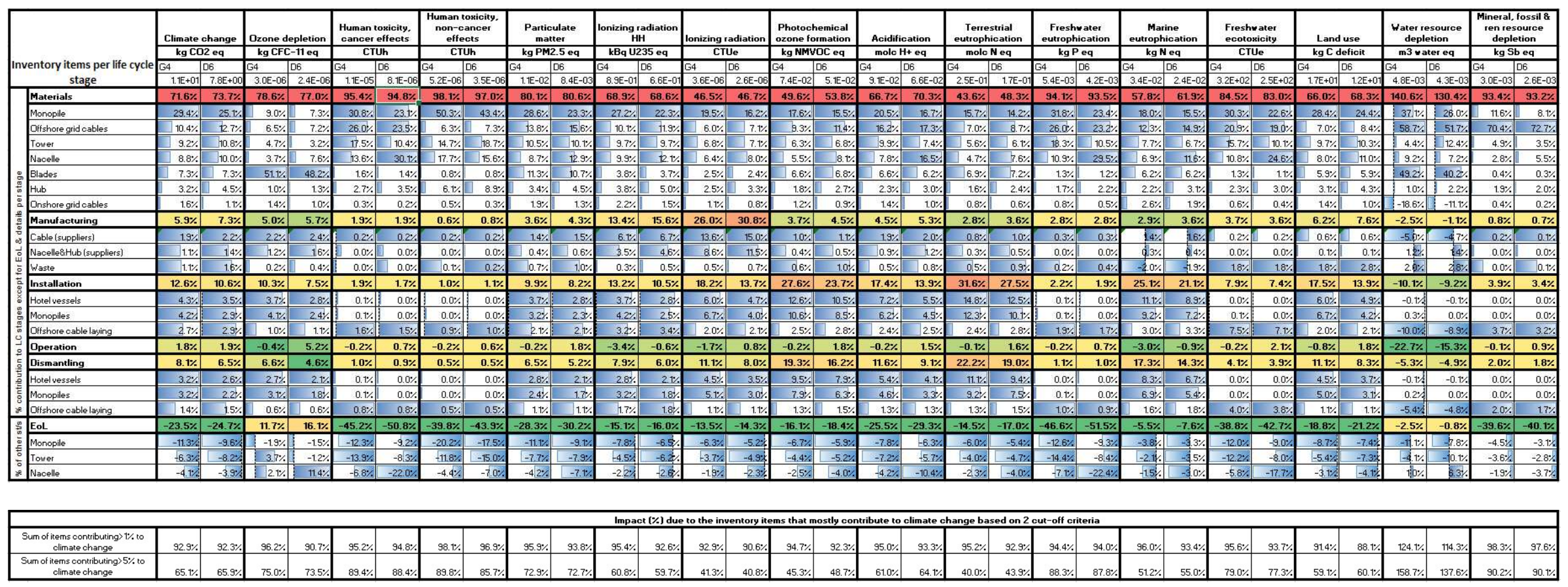
Bonou A, Laurent A, Olsen SI (2016) Life cycle assessment of onshore and offshore wind energy-from theory to application. Appl Energy 180:327-337. doi: 10.1016/j.apenergy.2016.07.058

Figure S1. Endpoint LCA results for ecosystem damages (\% contribution to species.yr)

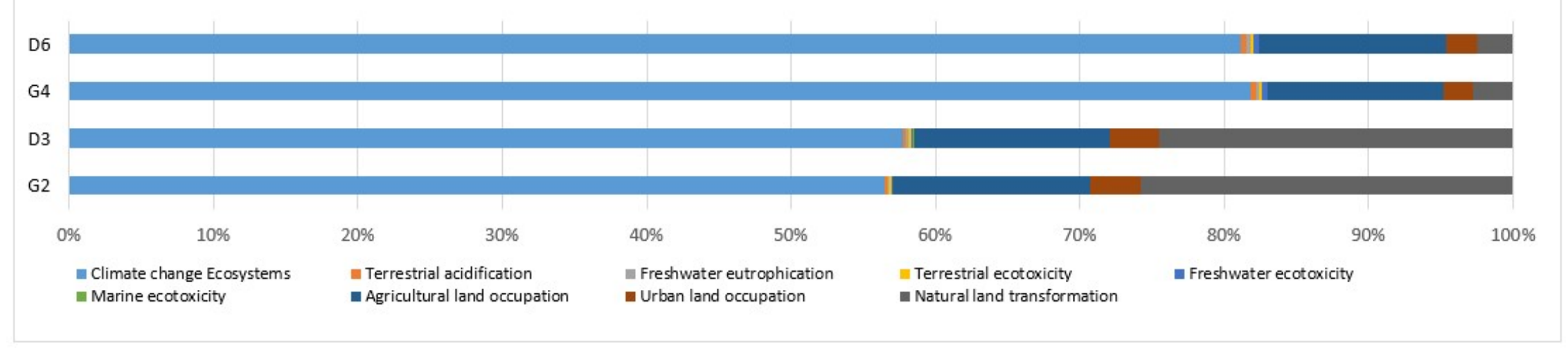

Figure S2. Uncetainty analysis for the LCA results of the D3 plant via Monte Carlo (1000 runs, confidence interval 95\%). Uncertainty due to inventory data only. 
Bonou A, Laurent A, Olsen SI (2016) Life cycle assessment of onshore and offshore wind energy-from theory to application. Appl Energy 180:327-337. doi: 10.1016/j.apenergy.2016.07.058

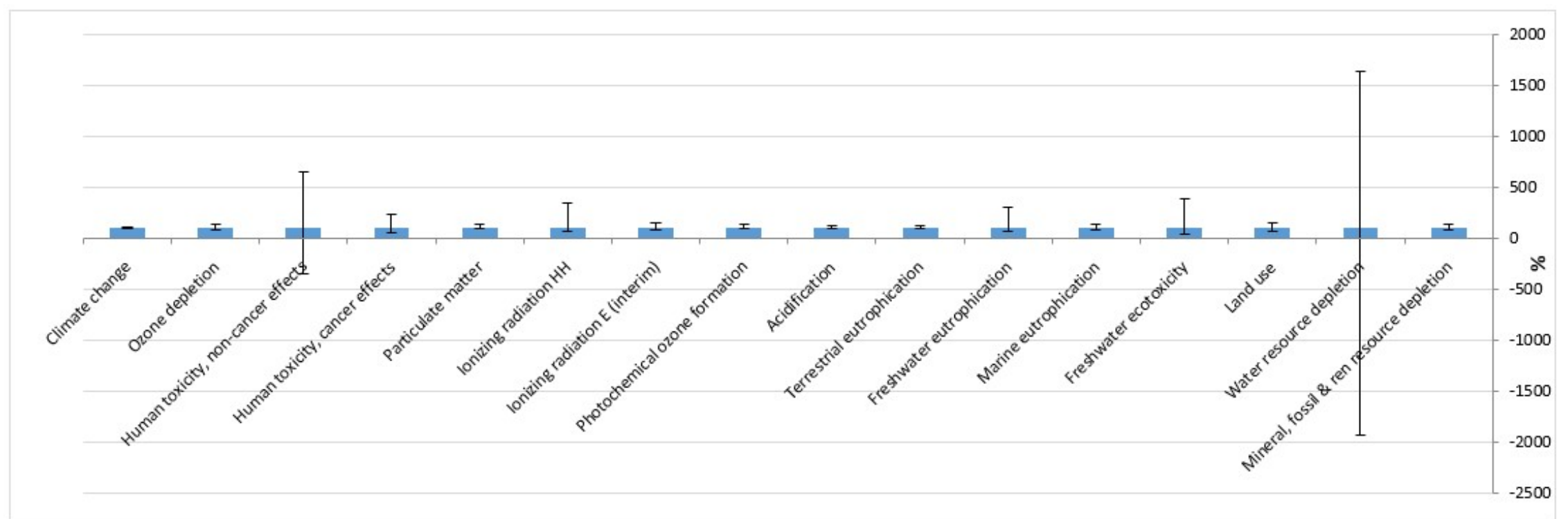

